\title{
Akuntansi Forensik Untuk Bedah Kasus Korupsi
}

\author{
Gita Claudia \\ email: gita@unika.ac.id \\ Program Studi Akuntansi, Fakultas Ekonomi dan Bisnis \\ Universitas Katolik Soegijapranata
}

\begin{abstract}
This study aims to see corruption case of driving license simulator procurement project from the forensic accounting side. The number of corruption cases in Indonesia has prompted the government to order all central and regional authorities to carry out any measures to combat corruption. The role of forensic accountants is needed in order to dismantle the number of fraud that comes from corruption. Forensic accounting provides an accounting analysis that can be used for debates in court which are the basis for discussion and resolution in court.

A forensic accountant is someone who understands forensic accounting. Forensic accountants have specialized expertise in accounting, auditing, finance, quantitative methods, specific areas of law, research, and investigative skills in gathering evidences, analyzing evidence, evaluating evidence, interpreting and communicating the results of the findings. This research explains the corruption case of driving license simulator project procurement of document evidence, physical evidence, testimonial evidence, and personal observation. From the findings of evidence by the forensic accountant, that can help solve the case of corruption driving license simulator procurement project.
\end{abstract}

Keyword: Accounting forensic, driving license simulator procurement project, document physical and testimonial evidence, personal observation.

\section{LATAR BELAKANG}

Saat ini sudah menjamur praktik - praktik korupsi hampir di setiap lini kehidupan di Indonesia. Hal tersebut terlihat sangat ironis dengan banyaknya strategi yang telah dirumuskan oleh berbagai lembaga pemerintahan seperti BPK, BPKP, Inspektorat, KPK maupun oleh kalangan LSM seperti MTI dan ICW. Seluruh strategi yang merupakan jurus-jurus ampuh dalam pemberantasan korupsi sepertinya belum mampu menuntaskan permasalahan korupsi yang sudah merajalela (Arles dan Anita, 2013).

Korupsi berdasarkan pemahaman UU No. 31 tahun 1999 jo. UU No. 20 tahun 2001 pasal 2 mengatakan korupsi adalah tindakan orang yang melawan 
hukum dengan melakukan perbuatan memperkaya diri sendiri atau orang lain atau suatu korporasi yang dapat merugikan keuangan negara atau perekonomian negara yang dari segi materiil perbuatan itu dipandang sebagai perbuatan yang bertentangan dengan nilai-nilai keadilan masyarakat.

Instruksi Presiden (Inpres) Nomor 5 Tahun 2004 tentang Percepatan Pemberantasan Korupsi berisi mengenai tindakan pemerintah yang memerintahkan semua aparat di pusat dan daerah menjalankan langkah-langkah apapun untuk memberantas korupsi. Upaya tersebut antara lain melalui sistem pengawasan ketat dalam pelayanan pajak dan imigrasi, mengawasi pengeluaran dan pendapatan, meningkatkan pelayanan masyarakat di pusat dan daerah, serta membawa ke meja hijau setiap kasus korupsi. Dalam rangka upaya percepatan pemberantasan tindak pidana korupsi tersebut, sebagai badan yang memiliki tujuan yang sama untuk memberantas tindak pidana korupsi, Kepolisian Negara Republik Indonesia, Komisi Pemberantasan Tindak Pidana Korupsi, Kejaksaan dan Pengadilan harus membuktikan kecurigaan mereka kepada seseorang mengenai apakah seseorang tersebut melakukan korupsi atau tidak. Pengusutan ini sangat sulit dilakukan karena berkaitan dengan bidang tertentu di luar hukum, yaitu bidang keuangan negara atau perekonomian negara. Agar dapat membuktikan apakah seseorang melakukan korupsi harus didukung oleh alat bukti yang memiliki tingkat pembuktian yang kuat. Alat bukti tersebut digunakan untuk membuktikan mengenai penyalahgunaan atau kecurangan yang telah dilakukan dalam tindak pidana korupsi. Untuk dapat memperoleh alat bukti juga diperlukan sebuah metode yang tepat dan relevan. Metode yang dapat digunakan adalah jasa analisis akuntansi forensik.

Awal dari akuntansi forensik di Indonesia terjadi pada bulan Oktober 1997, Indonesia memiliki kemungkinan untuk meminjam dana dari IMF dan World Bank. Dimana dana tersebut untuk menangani krisis keuangan yang semakin parah. Untuk hal tersebut, IMF dan World Bank memberi syarat mewajibkan adanya proses Agreed Upon Due Dilligence (ADDP) yang dikerjakan oleh akuntan asing dibantu beberapa akuntan Indonesia. Temuan ADDP terhadap sampel bank-bank besar di Indonesia menunjukkan perbankan 
melakuan overstatement asset sebesar 28\%-75\% dan understatement kewajiban sebesar 3\%-33\%. Temuan ini segera membuat panik pasar dan pemerintah yang berujung pada likuidasi 16 bank swasta. Likuidasi tersebut kemudian diingat menjadi langkah yang buruk karena menyebabkan adanya penarikan besarbesaran dana (Rush) tabungan dan deposito di bank-bank swasta karena hancurnya kepercayaan publik pada pembukuan perbankan. ADPP tersebut tidak lain dari penerapan akuntansi forensik atau audit investigatif. Istilah akuntansi forensik di Indonesia muncul setelah keberhasilan Pricewaterhouse Coopers (PwC) dalam membongkar kasus Bank Bali. Kantor PwC mampu menunjukkan arus dana yang rumit berbentuk seperi diagram cahaya yang mencuat dari matahari (sunburst). Kemudian PwC meringkasnya menjadi arus dana dari orang-orang tertentu. Sayangnya keberhasilan ini tidak diikuti dengan keberhasilan sistem pengadilan. Metode yang digunakan dalam audit tersebut adalah follow the money atau mengikuti aliran uang hasil korupsi Bank Bali dan in depth interview yang kemudian mengarahkan kepada para pejabat dan $\begin{array}{lllll}\text { pengusaha } & \text { yang } & \text { derlibat }\end{array}$ Kasus lainnya pada tahun 2006, Pusat Pelaporan dan Analisis Transaksi Keuangan (PPATK) mampu membuktikan kepada pengadilan bahwa Adrian Waworuntu terlibat dalam penggelapan L/C BNI senilai Rp 1.3 Triliun, dengan menggunakan metode follow the money yang mirip dengan metode PwC dalam kasus Bank Bali dalam kasus lain dengan metode yang sama PPTK juga berhasil mengungkapkan beberapa transaksi "ganjil" 15 Pejabat Kepolisian.

Peran akuntan forensik sangat dibutuhkan didalam menindak lanjuti korupsi agar dapat membongkar banyaknya terjadi kecurangan yang berasal dari korupsi. Tingkat korupsi yang masih tinggi menjadi pendorong yang kuat untuk berkembangnya praktik akuntansi forensik di Indonesia, meskipun pada dasarnya akuntansi forensik sudah lama dipraktikan di Indonesia jauh sebelum krisis ekonomi.

Keberhasilan pemberantasan tindak pidana korupsi sangat bergantung pada penyidikan dan pembuktian di persidangan serta tidak mengesampingkan pula proses lainnya seperti penyelidikan dan penuntutan. Penyidikan berperan 
untuk mengumpulkan fakta-fakta dan alat bukti, sedangkan pembuktian di persidangan adalah untuk membuktikan bahwa benar seorang terdakwa secara sah dan meyakinkan telah melakukan tindak pidana korupsi berdasarkan alat bukti yang sah. Dengan telah dilakukannya praktik akuntansi forensik di Indonesia belum dapat diukur apakah penerapan akuntansi forensik telah membantu pemberantasan tindak pidana korupsi atau belum. Oleh karena itu diperlukan pengkajian lebih lanjut mengenai eksistensi akuntansi forensik dalam penyidikan dan pembuktian tindak pidana korupsi.

Berdasarkan latar belakang tersebut, maka selanjutnya akan dibahas tentang peran akuntansi forensik dalam penyidikan tindak pidana korupsi dan pengaruh alat bukti hasil analisis akuntansi forensik terhadap putusan hakim pengadilan tindak pidana korupsi.

\section{KERANGKA TEORI}

Menurut Tuanakotta (2010) dalam Hakim (2014) Akuntansi forensik adalah ilmu akuntansi dalam arti luas termasuk auditing, pada masalah hukum untuk penyelesaian hukum di dalam atau di luar pengadilan. Akuntansi forensik meliputi investigasi kecurangan dan menginvestigasi pembukuan keuangan maupun catatan yang terkait dengan tindak pidana korupsi. Berbeda dengan auditor yang memberikan opini terhadap laporan keuangan, Akuntansi forensik lebih berfokus pada suatu dugaan atau peristiwa tertentu. Oleh karena itu, akuntansi forensik memiliki peran yang efektif dalam menyelidiki dan membuktikan adanya tindak pidana korupsi.

Menurut Wiratmaja (2010) akuntansi forensik, menyediakan suatu analisis akuntansi yang dapat digunakan dalam perdebatan di pengadilan yang merupakan basis untuk diskusi serta resolusi di pengadilan. Penerapan pendekatanpendekatan dan analisis-analisis akuntansi dalam akuntansi forensik dirancang untuk menyediakan analisis dan bukti memadai atas suatu asersi yang nantinya dapat dijadikan bahan untuk pengambilan berbagai keputusan di pengadilan. 
Akuntan forensik juga mempraktekkan keahlian khusus dalam bidang akuntansi, auditing, keuangan, metode-metode kuantitatif, bidang-bidang tertentu dalam hukum, penelitian, dan keterampilan investigatif dalam mengumpulkan bukti, menganalisis, dan mengevaluasi materi bukti dan menginterpretasi serta mengkomunikasikan hasil dari temuan tersebut.

Seorang akuntan forensik bertugas memberikan pendapat hukum dalam pengadilan (litigation). Disamping itu, ada juga peran akuntan forensik dalam bidang hukum diluar pengadilan (non itigation) misalnya dalam membantu merumuskan alternatif penyelesaian perkara dalam sengketa, perumusan perhitungan ganti rugi dan upaya menghitung dampak pemutusan / pelanggaran kontrak.

Akuntansi forensik dibagi ke dalam dua bagian:

- Jasa penyelidikan (investigative services) mengarahkan pemeriksa penipuan atau auditor penipuan, yang mana mereka menguasai pengetahuan tentang akuntansi mendeteksi, mencegah, dan mengendalikan penipuan, dan misinterpretasi.

- Jasa litigasi (litigation services) merepresentasikan kesaksian dari seorang pemeriksa penipuan dan jasa-jasa akuntansi forensik yang ditawarkan untuk memecahkan isu-isu valuasi, seperti yang dialami dalam kasus perceraian. Sehingga, tim audit harus menjalani pelatihan dan diberitahu tentang pentingnya prosedur akuntansi forensik di dalam praktek audit dan kebutuhan akan adanya spesialis forensik untuk membantu memecahkan masalah.

1. Kompentensi keahlian akuntansi forensik yang digunakan dalam penilaian yaitu

Analisis deduktif: kemampuan untuk menganalisis kejanggalan yang terjadi dalam laporan keuangan, yakni kejadian yang tidak sesuai dengan kondisi yang wajar.

2. Pemikiran yang kritis: kemampuan untuk membedakan antara opini dan fakta. 
3. Pemecahan masalah yang tidak terstruktur: kemampuan untuk melakukan pendekatan terhadap masing-masing situasi (khususnya situasi yang tidak wajar) melalui pendekatan yang tidak terstruktur.

4. Fleksibilitas penyidikan: kemampuan untuk melakukan audit di luar ketentuan/prosedur yang berlaku.

5. Analitik yang merupakan kemampuan untuk memeriksa apa yang seharusnya ada (yang seharusnya tersedia) bukan apa yang telah ada (yang telah tersedia).

6. Komunikasi lisan yang merupakan kemampuan untuk berkomunikasi secara efektif secara lisan melalui kesaksian ahli dan penjelasan umum tentang dasar-dasar opini.

7. Komunikasi tertulis yang merupakan kemampuan untuk berkomunikasi secara efektif dengan tulisan melalui laporan, bagan, gambar, dan jadwal tentang dasar-dasar opini.

8. Pengetahuan tentang hukum dimana merupakan kemampuan untuk memahami proses-proses hokum dasar dan isu-isu hukum termasuk ketentuan bukti (rules of evidence).

9. Composure, yaitu kemampuan untuk menjaga sikap untuk tetap tenang meskipun dalam situasi tertekan.

Dibanding akuntan lainnya, seorang akuntan forensik memiliki tugas yang paling berat. Tugas utama dari akuntan di perusahaan adalah mencatat dan menjaga kelancaran arus keuangan perusahaannya. Sedangkan auditor lebih seperti petugas patroli yang melakukan inspeksi dan pengecekan rutin atas area berdasarkan pengalaman mereka sebelumnya. Di Indonesia sendiri masih belum banyak akuntan yang mendalami bidang forensik ini.

Dari segi peminat, masih jarang akuntan Indonesia yang mendalami bidang yang satu ini. Tak semua kantor akuntan public membidangi forensik. Asosiasi profesi akuntan belum melirik forensik sebagai bagian penting dari akuntansi. Belum terlihat isu-isu khusus yang mendesak agar akunatnsi forensik diberi perhatian khusus, walaupun sebenarnya kasus korupsi yang sudah marak 
terjadi dapat dijadikan salah satu motor untuk mengembangkan akuntansi forensik di Indonesia.

\section{PEMBAHASAN DAN ANALISIS}

Peran akuntansi dan akuntan forensik di negara maju dalam pengungkapan dan penyelesaian kasus fraud termasuk korupsi sangatlah besar. Sayangnya Indonesia belum memiliki lembaga legal untuk profesi dan juga institusi pendidikan formal untuk menghasilkan akuntan forensik yang kompeten. Kondisi ini tentu membutuhkan perhatian dari profesi akuntan di Indoensia khususnya dari kompartemen akuntan pendidik maupun kompartemen lainnya. Perhatian tersebut dapat berupa sumbangan kajian empiris atau konseptual mengenai bagaimana kelembagaan ideal dari profesi akuntan forensik di Indonesia dan bagaimana sistem pendidikan dan kurikulum ideal untuk menghasilkan tenaga akuntan forensik yang kompeten (Wiratmaja, 2010).

Salah satu contoh kasus korupsi yang akan dibedah pada tulisan ini adalah proyek pengadaan driving simulator SIM untuk kendaraan roda dua dan roda empat yang menggunakan dana anggaran tahun 2011, dimana muncul ketidakwajaran menggunakan anggaran yang tidak semestinya. Simulator surat ijin mengemudi (SIM) ini diperuntukkan masyarakat umum.

Kasus ini melibatkan Kepala Korps Lalu Lintas (Kakorlantas) Mabes Polri, Inspektur Jendral Polisi Djoko Susilo terkait kasus dugaan korupsi proyek pengadaan alat Simulator SIM di Korps Lalu Lintas (Korlantas) Mabes Polri.

Berawal saat PT Citra Mandiri Metalindo Abadi (CMMA), perusahaan milik Budi Susanto, menjadi pemenang tender proyek untuk pengadaan untuk simulator SIM. Terdapat markup lebih dari Rp10 miliar dalam pengadaan 700 unit simulator R2 dan kelebihan Rp11 miliar dalam pengadaan 569 alat simulator R4 sehingga terjadi kelebihan harga. Perusahaan ini membeli barang dari PT Inovasi Teknologi Indonesia (ITI) senilai total Rp 90 miliar. Harga simulator sepeda motor Rp 42,8 juta per unit Harga simulator mobil Rp 80 juta per unit Nilai total tender proyek simulator SIM yang dimenangkan PT CMMA mencapai Rp 198,7 miliar. Harga simulator sepeda motor adalah Rp 77,79 juta per unit, total Rp 54,453 miliar 
untuk 700 simulator sepeda motor. Harga simulator mobil Rp 256,142 juta per unit, total Rp 142,415 untuk 569 buah simulator mobil. Perusahaan milik Budi Susanto itu memperoleh untung lebih dari 100 persen, yakni Rp 116 miliar.

Dalam tugasnya sebagai akuntan forensik, maka beberapa hal perlu diselidiki untuk mengumpulkan bukti-bukti yang nantinya dapat dibawa ke pengadilan.

Berikut adalah penyidikan yang dilakukan dengan mengumpulkan fakta-fakta dan alat bukti :

\section{Documentary Evidence}

Bukti dokumen berupa:

\section{- Surat Perjanjian Kontrak Secara Tertulis}

Bukti dokumen dalam kasus ini berupa surat perjanjian kontrak secara tertulis tentang pengadaan alat Simulator SIM. Dalam surat perjanjian, total total nilai kontrak sebesar Rp 169 miliar, namun ternyata terjadi mark up atau penggelembungan anggaran sebesar Rp 100 miliar. Selain itu kerugian juga bersumber dari ketidak sesuaian spesifikasi barang dengan perjanjian yang tertera dalam kontrak senilai Rp 21 miliar. Ketidak sesuain spesifikasi tersebut dapat ditemukan setelah dilakukan pengecekan secara fisik atas simulator motor dan mobil.

\section{- Dokumen Lelang}

Terdapat bukti dokumen lainnya berdasarkan hasil audit investigasi BPK yaitu dokumen lelang fiktif. Dokumen perusahaan yang mengikuti tender selain PT CMMA dan PT ITI (PT Bentina Agung, PT Digo Mitra Slogan, PT Dasma Pertiwi, dan PT Kolam Intan) merupakan dokumen yang fiktif yang hanya digunakan sebagai formalitas dan untuk menunjukkan bahwa tender pengadaan barang dan jasa ini berjalan sesuai dengan prosedur yang ada. Sebab dari awal, PT CMMA memang telah dirancang untuk menjadi pemenang tender tersebut sehingga modus tersebut dilakukan demi menutupi segala kejanggalan. 


\section{Physical Evidence}

Bukti fisik menjadi bukti nyata bahwa memang pengadaan simulator SIM ini dilakukan tidak sesuai dengan prosedur yang ada. Bukti fisik yang ditemukan antara lain alat simulator SIM dan tanda tangan palsu.

- Bukti Tanda Tangan Palsu

Ditemukan bukti tanda tangan palsu yang dilakukan Didik Purnomo, merupakan pejabat pembuat komitmen dalam proyek pengadaan simulator uji klinik pengemudi roda dua (R2) dan roda empat (R4) tahun anggaran 2011. Dalam kasus ini Didik telah memalsukan tanda tangan Djoko Susilo untuk mempercepat pencairan dana. Walaupun Didik terus membantah hal tersebut selama sidang pemeriksaan minggu lalu. Bukti ini mengindikasikan bahwa terdapat uang korupsi yang diterima Didik Purnomo sehingga ia bersedia memperlancar kasus korupsi ini.

Djoko menyatakan, dirinya tidak mengetahui soal pencairan dana pembayaran simulator SIM. Pernyataan tersebut membuat JPU KPK Kms Ronnie bertanya, bagaimana bisa seorang polisi dengan pangkat di bawahnya yakni Komisaris Polisi (Kompol) berani membuat tandatangan palsu atasannya yang berpangkat jenderal bintang. Dalam kasus ini terdapat bukti berupa pemalsuan tanda tangan Djoko yang bertujuan untuk melakukan pencairan dana.

Dalam kasus simulator SIM ini, 20 kardus cokelat dipindahkan dari kontainer ke mobil Innova hitam yang terparkir di depan kontainer. Sedikitnya enam penyidik KPK bahu membahu memindahkan kardus-kardus yang berisi barang bukti tersebut.

Selesai dimasukkan ke dalam mobil, barang-barang bukti dalam kardus tersebut dibawa masuk ke Gedung KPK dengan mobil.

Dalam pelaksanaan proyek Simulator SIM, PT CMMA diduga membeli barang dari PT Inovasi Teknologi Indonesia sekitar Rp90 miliar. Harga barang yang dibeli ini jauh lebih rendah dari nilai kontrak yang dimenangkan PT CMMA, sehingga perusahaan itu memperoleh keuntungan sekitar Rp100 miliar. 
Selain itu, barang bukti yang telah disita dan dirampas untuk negara sebagaimana diputus Pengadilan Tipikor Jakarta Pusat dirampas untuk negara ditambah barang bukti berupa rumah seluas $377 \mathrm{~m} 2$ berikut bangunan dan SHGB No. 156/ Tanjung Barat yang terletak di jalan Cendrawasih Mas Blok A. 9 No. 1 RT 002, RW 01 Kelurahan Tanjung Barat, Kecamatan Jaga Karsa, Jakarta Selatan, serta 2 unit mobil Toyota Avanza dirampas untuk negara.

\section{- $\quad$ Alat simulator SIM}

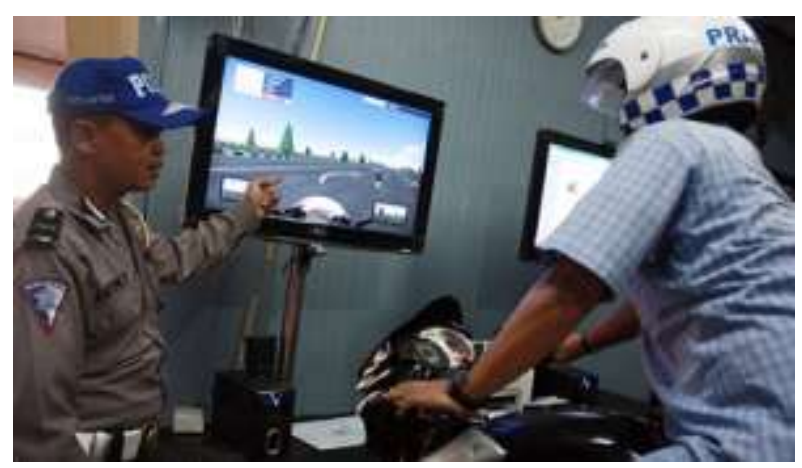

Alat simulator SIM merupakan salah satu bukti fisik yang memperkuat adanya pelanggaran surat perjanjian kontrak. Toto Hardianto (dosen pada Institut Teknologi Bandung (ITB) dengan spesialisasi teknik mesin) menjelaskan bahwa berdasarkan pemerikasaan fisik simulator motor dan mobil pada 272 tempat yang tersebar di 33 provinsi ditemukan spesifikasi yang tidak sesuai dengan kontrak dan Undang-Undang, bahkan ada banyak alat yang tidak berfungsi.

\section{Testimonial Evidence}

Dalam rangka mengumpulkan bukti, auditor banyak meminta keterangan secara lisan dari klien terutama para manajer. Jawaban lisan yang diperoleh dari permintaan keterangan tersebut merupakan tipe bukti testimonial evidence

Bukti testimonial merupakan keterangan secara lisan dari Warsono Sugantoro dan Sukotjo S Bambang, Direktur PT Inovasi Teknologi Indonesia (ITI)

\section{- Warsono Sugantoro}

Warsono Sugantoro alias Jumadi merupakan saksi terdakwa Djoko Susilo dan adalah orang yang mendapat jatah dari pemenangan PT CMMA. Dia ditugaskan oleh Direktur PT Inovasi Teknologi Indonesia Sukotjo Bambang (melalui staf Sukotjo yaitu Pak Morde) mencari perusahaan yang bisa dipinjam benderanya untuk mengikuti lelang fiktif. 
Warsono mengaku mendapat jatah $\mathrm{Rp} 5$ juta per perusahaan karena membawa empat perusahaan untuk ikut proses lelang proyek tersebut.

"Saya mendapat imbalan jasa Rp 5 juta per perusahaan," kata Warsono dalam pengakuannya di Pengadilan Tindak Pidana Korupsi (Tipikor), Jakarta, Selasa $(21 / 5)$.

Dari keempat perusahaan itu, Warsono mendapat jatah Rp20 juta dan tambahan jatah Rp5 juta dari Sukotjo Bambang. Dengan demikian, Warsono mendapat jatah Rp25 juta setelah berhasil membawa empat perusahaan itu dalam proses lelang proyek pengadaan alat simulator SIM.

- $\quad$ Sukotjo S Bambang, Direktur PT Inovasi Teknologi Indonesia (ITI)

Sukotjo juga merupakan saksi kunci kasus Simulator SIM yang mengungkapkan dugaan praktek korupsi dalam proyek alat uji kemudi simulator SIM. Sukotjo menyatakan bahwa penggelembungan dana pada jumlah anggaran yang dibutuhkan untuk proyek pengadaan dilakukan dengan menuliskan komponen yang sebenarnya tidak digunakan dalam perakitan simulator. Contohnya, harga untuk kursi penumpang di sebelah kiri pengemudi dan sabuk pengamannya yang sebenarnya tidak perlu dan tidak ada namun tetap dicantumkan. Kemudian, ada beberapa harga komponen-komponen yang ditulis ulang.

\section{Personal observation}

Personal observation adalah penggunaan indera perasa untuk menilai aktivitas-aktivitas tertentu. Sepanjang proses audit, terdapat banyak kesempatan bagi auditor untuk mempergunakan indera penglihatan, pendengaran, perasa, dan penciumannya dalam mengevaluasi berbagai item yang sangat beraneka ragam. Merupakan kewajiban auditor untuk menindaklanjuti berbagai kesan pertama yang didapatnya dengan berbagai bentuk bukti audit lainnya yang bersifat nyata.

\section{- Alat Simulator SIM yang Tidak Sesuai dengan UU}

Dalam proses investigasi, KPK meminta Toto Hardianto bersama tim pusat rekayasa industri ITB untuk melakukan observasi atas alat simulator SIM milik Korlantas yang dibuat oleh PT CMMA. Toto Hardianto adalah seorang 
dosen pada Institut Teknologi Bandung (ITB) dengan spesialisasi teknik mesin. Tim menekankan pengujian pada spesifikasi alat Simulator SIM R2 dan R4, termasuk penentuan harga pokok produksi (HPP). Tim mengidentifikasi 543 unit dari 700 unit Simulator R2 dan 398 unit R4 dari 556 unit yang dianggap paling baik kondisinya

Setelah dilakukan observasi pada alat simulator ditemukan bahwa pengadaan simulator SIM tidak sesuai dengan spesifikasi yang ditetapkan Undang-undang. Sesuai UU, menyebutkan bahwa Simulator SIM yang diharuskan adalah Simulator yang bisa menguji reaksi, antisipasi, pertimbangan sikap mengemudi dan konsentrasi peserta uji SIM.

Jumat (19/7), Toto menyatakan :

"Kami simpulkan Simulator SIM yang ada (milik Korlantas) memang tidak bisa menguji secara total dari mengemudi. Karena fungsinya tidak mewakili seluruh parameter uji SIM".

Toto dan tim juga menemukan bahwa Simulator belum terinstal, padahal dalam perjanjian jual beli Simulator harus sudah terinstal. Simulator yang ada hanya bisa menguji peserta yang ada di dalam database dan beberapa fungsi utama alat Simulator dapat bekerja, tapi tidak lengkap.

Selain itu, tim juga menemukan kegagalan fungsi pada alat Simulator SIM. Diantaranya pada fungsi hidrolik yang tidak berfungsi, sound system tidak berfungsi, micro controler juga tidak dapat bekerja dan software juga tidak berfungsi untuk seluruh fungsi.

Dengan bukti-bukti yang telah dikumpulkan, maka seorang akuntan forensik dapat maju ke pengadilan dan pada hasilnya, tersangka utama Djoko Susilo dikenakan pelanggaran terhadap pasal-pasal:

- Pasal 2 ayat (1) juncho Pasal 18 Undang-undang Pemberantasan Tipikor juncto

- Pasal 55 ayat (1) juncho

- Pasal 65 ayat (1) ke-1 Kitab Undang-undang Hukum Pidana 
- Pasal 3 Undang-undang Republik Indonesia nomor 31 tahun 1999 jo UU No

20 tahun 2001 tentang Penyalahgunaan Wewenang dan Perbuatan

Memperkaya Diri

Pada akhirnya Majelis Hakim Mahkamah Agung menguatkan putusan Pengadilan Tinggi DKI Jakarta dengan hukuman :

- Penjara 18 tahun

- Denda 1 miliar

- Uang pengganti 32 miliar

- Penyitaan aset-aset milik Djoko Susilo

- Walaupun tidak dengan surat bulat, MA tetap mencabut hak Djoko Susilo dalam politik

\section{KESIMPULAN DAN SARAN}

Korupsi sebagian besar dilakukan oleh orang-orang yang memiliki wewenang dan berusaha menyelewengkan wewenang mereka demi kepentingan pribadi. Korupsi sendiri tentunya merugikan negara karena pihak-pihak yang melakukan korupsi memiliki wewenang yang dapat menjadi sumber uang bagi mereka terutama dana anggaran negara.

Kasus korupsi yang melibatkan Djoko Susilo sebagai aparat hukum negara untuk memperlancar tender pengadaan simulator SIM. Hal ini menunjukkan adanya penyalahgunaan wewenang oleh pejabat tinggi dan terjadi suap terhadap penjabat tinggi. Selain itu, Djoko Susilo terbukti melakukan pencucian uang dengan menyamarkan, menyembunyikan, atau mengaburkan kepemilikan harta kekayaannya yang diperoleh dari kasus korupsi ini.

Dalam penanganan kasus korupsi, peran akuntan forensik sangat dibutuhkan dimana dengan penyidikan mengumpulkan barang-barang bukti mampu membawa kasus-kasus korupsi ke pengadilan. Dengan adanya bukti-bukti yang kuat maka jaksa mampu menuntut tersangka korupsi dengan hukuman yang berat. Kemampuan seorang akuntan forensik dalam menangani kasus-kasus korupsi sangat diperlukan, terutama saat mengumpulkan barang-barang bukti 
dengan melakukan penelusuran aliran dana yang masuk dalam rekening-rekening maupun kantong para koruptor. Disebutkan bahwa tugas salah satu dari akuntan forensik adalah mengawasi pergerakan arus kas dan di kasus pengadaan simulator SIM diatas terungkap pula bahwa perjanjian nilai kontrak dengan anggaran yang diajukan, dimana nilai kontrak tersebut tidak sesuai dengan spesifikasi simulator SIM.

Akuntansi forensik dalam kasus-kasus korupsi inilah yang mempu membawa kasus korupsi ke pengadilan dan menjebloskan para koruptor ke dalam penjara. Meskipun belum bnayak akuntan yang mendalami akuntansi forensi, maka perlu adanya lembaga yang berdiri untuk mempelajari teknik-teknik akuntansi forensik dan sertifikasi yang mengakui kualitas seorang akuntan forensik.

\section{DAFTAR PUSTAKA}

Arles, Leardo dan Anita.2013.”Akuntansi Forensik dalam Upaya Pemberantasan TIndak Pidana Korupsi di Indonesia”.Jurnal Mahasiswa Creative Universitas Riau

Astuti, Ni Putu Sri.2013.’Peran Audit Forensik dalam Upaya Pemberantasan Korupsi di Indonesia”.Universitas Negeri Surabaya.

Hakim, Uminah.2014.’Eksistensi AKuntansi Forensik dalam Penyelidikan dan Pembuktian Pidana Korupsi”. Unnes Law Jurnal 3 (1).

Sayydid, Annisa.2014."Pemeriksaan Fraud dalam Akuntansi Forensik dan Audit Investigatif". Jurnal Vol. 13, No.2, Juli-Desember 2014 hlm.137-162

Wiratmaja, I Dewa Nyoman.2010.”Akuntansi Forensik dalam Upaya Pemberantasan Tindak Pidana Korupsi”.Jurusan Akuntansi, Fakultas Ekonmi Universitas Udayana.

Instruksi Presiden Republik Indonesia Nomor 5 tahun 2004 Tentang Percepatan Pemberantasan Korupsi

Undang-undang Republik Indonesia Nomor 31 Tahun 1999 tentang Pemberantasan Tindak Pidana Korupsi 
http://www.cnnindonesia.com/nasional/20150826114934-12-74561/kpk-sidik-

empat-polisi-kasus-simulator-sim/ diunduh pada 1 Juli 2016 pukul 21:14

berkas.dpr.go.id diunduh pada 1 Juli 2016 pukul 21:30

https://imagama.feb.ugm.ac.id/akuntansi-forensik/ diunduh pada 9 Juli 2016 pukul $11: 35$ 